\title{
HAK-HAK POLITIK WARGA NEGARA NON MUSLIM SEBAGAI PEMIMPIN DALAM PANDANGAN HUKUM ISLAM DAN HUKUM POSITIF
}

\author{
Dudi Badruzaman, STAI Sabili Bandung, Jl. Gagak No.15, Sadang Serang, Coblong, Kota \\ Bandung, Jawa Barat, E-mail: badruzaman.dudi@yahoo.com
}

\begin{abstract}
Leaders are very important in a country, in the life of the state the community has political rights such as the right to choose and be elected. however, regarding the chosen rights of nonMuslims as leaders, it became a controversy in Islamic law because of the differences of opinion between classical scholars and contemporary ulama for that there needs to be a detailed discussion about the ability of a non-Muslim to become a leader. the formulation of the problem in this study is how the political rights of non-Muslim citizens in the view of Islamic law and positive law, and whether there are differences and similarities in the political rights of non-Muslim citizens in the view of Islamic law and positive law. The research method that the author did was LibraryResearch research with a normative approach and legal comparison method. The technique of data collection is done by studying the literature sourced from the 1945 Constitution, Law, AlQur'an, Hadith and opinions of scholars and legal experts in Indonesia. At the stage of data analysis, data is processed and utilized in such a way as to be able to deduce truths that can be used to answer the problems in this study.
\end{abstract}

Keywords: legal views, leaders, non-Muslims.

\section{PENDAHULUAN}

\section{Latar Belakang}

Dalam Kehidupan bernegara, masyarakat memiliki beberapa hak dan kewajiban yang diatur dalam undang-undang negara. Seperti hak untuk mendapatkan perlindungan hukum, hak menyampaikan pendapat, hak beragama, hak untuk membela negara serta hak-hak lain nya. Di dalam pemerintahan warga negara berperan penting demi jalan nya pemerintahan yang baik. Karena itu masyarakat memiliki beberapa hak hak dalam pemerintahan yang berupa hak politik. Seperti memberikan suaranya ketika pemilu, kemudian hak untuk memilih dan hak untuk dipilih sebagai kepala daerah, wakil rakyat atau memegang peranan dipemerintahan. ${ }^{1}$

Saat ini sebuah negara dibangun tidak hanya berdasarkan satu keyakinan saja, tetapi banyak keyakinan yang dipercaya oleh masyarakatnya. Dalam negara demokrasi tidak dapat perbedaan antara hak-hak yang dimiliki oleh pemeluk kepercayaan satu dengan yang lainnya. Negara memandang sama hak-hak warga negara selama dia menjadi warga negara tersebut. ${ }^{2}$

Berbeda dengan negara berdasarkan demokrasi ataupun yang liberal, negara yang menjadikan Islam sebagai landasan hukum nya tidak memberikan hak istimewa nya kepada masyarakat non Muslim. Islam menganggap mereka sebagai warga negara yang dilindungi tetapi Islam tidak membedakan manusia seperti ayat diatas melainkan Islam sangat menghormati hak-hak non Muslim.

Penetapan hak-hak non muslim dalam Islam, baik yang bersifat politik dan non politik, merupakan satu bagian yang tidak terpisahkan dari penetapan Islam bagi

\footnotetext{
1 David Litle Dkk. Kebebasan Agama dan Hak-hakAsasi Manusia, Pustaka Pelajar, Bandung, 2005, h. 6.

2 Ibid, h. 23.
} 
prinsip-prinsip keadilan, kebebasan dan persamaan hak setiap individu Daulah Islamiyah dihadapan undang-undang. Penetapan prinsip-prinsip itu ada dalam kitab Allah dan penjelasan dari sunnah nabawi yang menyatakan prinsip-prinsip itu merupakan dasar-dasar yang baku dalam syariat Islam dan pilar-pilar yang kokoh dalam struktur sistem politik bernegara Islam.

Ketika piagam madinah atau konstitusi negara baru menetapkan bahwa orang-orang nonMuslim adalah umat yang sama dengan kaum Muslimin, maka dengan demikian piagam itu telah menjadiakan mereka sebagai warga negara dan mempunyai hak seperti yang dimiliki oleh kaum Muslimin. Mereka juga mempunyai kewajiban sebagaimana kewajiban yang miliki kaum Muslimin mereka sama dalam negara itu, mereka bebas menjalankan agama mereka dan kaum muslimin juga bebas menjalankan agama nya, dan mereka masing-masing berhak memberi nasihat dan dinasihati, serta berbuat baik dan tidak berbuat jahat.

Dalam teks Piagam Nabawi ada dalil syar'i yang pasti mengukuhkan "hak warga negara" secara sempurna untuk ahli kitab dalam masyarakat muslim dan dalam daulah Islamiyah. Nash-nash dan bukti lainnya juga menguatkan akan hal itu. Pada nash-nash inilah kami berpegang dalam menetapkan dua hak memilih dan dipilih menjadi anggota dewan, yang kedua hak tersebut termasuk dalam hak-hak politik prioritas yang berhubungan dengan hukum dan administrasi, dan dengan terwujudnya keikutsertaan para warga negara lainnya dalam hak-hak politik prioritas dengan jalan langsung maupun tidak langsung.

Penetapan dua hak dari hak-hak politik untuk nonmuslim di negara Islam ini tidak dilarang dalam Islam, dan tidak mengapa partisipasi nonmuslim dalam menggunakan dua hak ini, karena mereka umat yang sama dalam kaum muslimin. Dua hak ini tidak lah termasuk dari sifat keagamaan yang menjadi dasar untuk membedakan antara warga negara, artinya harus ada syarat Islam dalam diri seseorang yang melaksanakan nya. Beberapa peneliti kontemporer juga telah menyimpulkan seperti ini.

Abdul Karim Zidan berkata dalam masalah yang berhubungan dengan hak memilih dan dipilih, serta hak partisipasi dalam memilih presiden di negara islam:" menurut kami, hukum yang paling jelas adalah boleh, sebab jabatan presiden dimasa sekarang tidak mempunyai bentuk kata keagamaan dan partisipasi sebagaimana dahulu. Oleh karena itu, ia bukanlah kekhalifahan yang banyak dibicarakan oleh para fukaha sekalipun masih ada sedikit makna yang sama". Jabatan presiden adalah jabatan kepemimpinan didunia dan bukan kekhalifahan yang diberikan Rasulullah SAW dalam memelihara agama dan politik dunia, ini adalah definisi kekhalifahan Al-Mawardi.

Berdasarkan hal ini, orang-orang kafir dzimmi boleh berpartisipasi dalam pemilihan umum sebab mereka tidak dilarang untuk ikut serta dalam urusan urusan duniawi. Sedangkan untuk memilih wakil-wakil mereka dalam Majelis Permusyawaratan Rakyat dan pencalonan dirinya sebagai anggota dewan,kami juga berpendapat boleh, sebab kanggotaan dalam majelis permusyawaratan rakyat artinya memberikan usulan juga memberikan nasihat kepada pemerintah dan ini adalah perkara-perkara yang tidak ada 
larangan nya bagi orang-orang kafir dzimmi untuk melakukannya dan ikut serta didalamnya. ${ }^{3}$

Selama sistem hukum dalam negara Islam adalah musyawarah dan syariat Islam sebagai sumber undang-undang didalam nya yakni tidak ada satu undang-undang negara pun yang menyalahi satu dasar dari dasar-dasar Islam yang baku, juga terwujud didalamnya keadilan politik dan keadilan sosial bagi seluruh rakyat, maka sistem itu adalah sistem hukum Islam, sekalipun berbeda struktur dan nama. Adapun yang menjadi dasar kita menetapkan hak-hak politik non muslim adalah prinsip warga negara yang sempurna yang telah ditetapkan untuk mereka di dalam Piagam Madinah dan dijadikan sebagai kaidah konstitusional Islam, yakni bahwa mereka itu umat yang sama dengan kaum mukminin. ${ }^{4}$

Mereka semua berhak menasihati dan dinasihati serta diperlakukan dengan baik, tidak dengan perlakuan jahat. Piagam itu juga menetapkan bahwa yahudi yang tinggal bersama kaum mukminin di Madinah adalah termasuk warga negara Islam, mereka mempunyai hak dan kewajiban sama seperti yang di miliki dengan kaum muslimin sebagaimana Piagam Madinah menetapkan hal semacam itu kepada kabilah-kabilah yahudi lainnya.

Di Indonesia di dalam hukum positif hak-hak politik meliputi hak untuk ikut serta dalam pemerintahan yaitu hak memilih dan dipilih, hak dipilih merupakan bagian dari HAM yaitu hak politik, hak untuk dipilih dapat dipergunakan untuk menentukan seseorang menduduki jabatan posisi publik maupun non pubik. Pengaturan mengenai hak untuk dipilih terdapat dalam pasal 21 UDHCR, kemudian terdapat dalam pasal 25 kovenan internasional hak sipil dan politik, pasal 27 ayat 1 dan pasal 28D ayat 3 UndangUndang Negara Republik Indonesia Tahun 1945, Pasal 43 ayat 1 Undang-Undang Nomor 39 Tahun 1999 tentang HAM.

\section{Rumusan Masalah}

Adapun rumusan masalah dalam penulisan ini adalah :

1. Bagaimanakah analisis terhadap hak-hak politik bagi warga negara non muslim menurut hukum Islam dan hukum positif?

2. Adakah perbedaan dan persamaan hak-hak politik warga negara non muslim dalam pandangan hukum islam dan hukum positif?

\section{METODE PENELITIAN}

Agar kegiatan praktis dalam penelitian dan penyusunan karya ilmiah ini terlaksana dengan objektif, ilmiah serta mencapai hasil yang optimal, maka penulis merumuskan beberapa macam langkah atau metode penelitian yang dipakai dalam karya ilmiah ini adalah metode deskriptif. Hal ini di maksudkan agar penulisan karya ilmiah sesuai dengan syarat ilmiah yang sudah ditentukan. Adapun syarat-syarat tersebut terdapat di dalam metode sebagai berikut :

\footnotetext{
${ }^{3}$ Mujar Ibnu Arif, Hak-hak Politik Minoritas Non Muslim dalam Komunitas Islam , Bandung: Angkasa, h. 36 .

${ }^{4}$ Farid Abdul Khaliq, Fikih Politik Islam, Jakarta: Sinar Grafika, 2005, h. 178.
} 
1. Jenis Penelitian Penelitian ini menggunakan metode Library Researchdengan Pendekatan normatif yang mana penelitian ini dilakukan dengan meneliti bahan pustaka atau data sekunder.Penelitian ini juga menggunakan metode perbandingan hukum (Komparatif), dalam hal ini penulis membandingkan antara Hukum Islam dan Hukum Positif mengenai hak warga negara non Muslim. ${ }^{5}$

2. Sumber data penelitian

a) Sumber data primer yaitu data. ${ }^{6}$

Bahan hukum primer merupakan bahan hukum yang bersifat autoritatif artinya mempunyai otoritas. Bahan-bahan hukum primer terdiri dariAl-Qur'an dan Hadist, Universal Declaration Of Human Right (UDHCR), Undang-Undang Dasar Negara Republik Indonesia Tahun 1945, Undang-Undang Nomor 39 Tahun 1999 tentang HAM.

b. Sumber Sekunder merupakan sumber yang diperoleh untuk memperkuat data yang diperoleh dari data primer yaitu, buku-buku, makalah-makalah, jurnal-jurnal, majalah, artikel, internet, dan sumber-sumber yang berkenaan dengan penelitian ini. $^{7}$

3. Teknik pengumpulan dan pengolahan data

a. Teknik pengumpulan data Teknik pengumpulan data yang digunakan dalam penelitian ini adalah kajian kepustakaan yaitu upaya pengidentifikasi secara sistematis dan melakukan analisis terhadap dokumen-dokumen yang memuat informasi yang berkaitan dengan tema, objek dan masalah penelitian yang dilakukan. 8

b. Teknik Pengolahan data Pengolahan data merupakan bagian yang amat penting dalam metode ilmiah, karena dengan pengolahan data, data tersebut dapat diberi arti dan makna yang berguna dalam memecahkan masalah.

4. Teknik Analisis Data

Teknik Analisis data adalah proses penyederhanaan data kedalam bentuk yang lebih mudah dibaca atau mudah dipahami dan diinformasikan kepada orang lain.Pada tahapan analisis data, data diolah dan dimanfaatkan sedemikian rupa hingga dapat menyimpulkan kebenaran-kebenaran yang dapat dipakai untuk menjawab persoalan yang diajukan dalam penelitian ini. Adapun data-data tersebut dianalisis menggunakan metode Komparatif analisis yaitu membandingkan kedua hukumdengan memberikan suatu gambaran secara jelas sehingga menemukan jawaban yang diharapkan. ${ }^{9}$

\section{LANDASAN TEORI}

Teori tentang politik dalam Islam telah banyak dikemukakan oleh para ulama baik di masa lampau atau pun di masa kini, hal ini mudah dipahami, karena masalah politik

\footnotetext{
${ }^{5}$ Juliansyah Noor, Metodologi Penelitian, Jakarta: Kencana Prenada Media Grup, 2011, h. 33.

${ }^{6}$ Kartini Kartono, Pengantar Teknologi Riset Sosial, Bandung: Mandar Maju, 1996, h.28.

7 Susiadi AS, Metodelogi Penelitian, Bandar Lampung: LP2M IAIN Raden Intan, h. 75.

8 J.Moelang, Metode Penelitian Kualitatif, Bandung: Remaja Rosada Karya, 1997, h.17.

9 Sugiyono, Metode Penelitian Kualitatif dan Kuantitatif, Bandung: Alfabeta, 2004, h.244.
} 
termasuk ruang lingkup ijtihad yang memungkinkan kepada ulama untuk mengkaji setiap masa.

Islam merupakan maanhaj ketuhanan yang diturunkan kepada Nabi Besar Muhammad SAW untuk umat manusia agar mereka berada dijalan yang benar dan selamat dunia akhirat, di lihat dari sejarah sebelum datang Islam, keadaan manusia pada waktu itu berada dalam keadaan jahiliyyah, kehidupan beragama di jazirah Arab sebelum Islam adalah penyembah berhala, mereka telah menyimpang jauh dari ajaran ketuhanan yang dibawa oleh nabi nabi mereka. Selain penyembahan berhala juga terjadi peperangan antara kabilah, terjadi perbudakan, dan hal-hal lain yang berbau jahiliyyah.

Atas dasar ini kedaulatan negara Islam atas warga nya yang bukan Islam terbagi menjadi dua macam yaitu Dzimmi yaitu seorang bukan Muslim yang tinggal dalam wilayah negara Islam dengan ketentuan bahwa ia mempunyai hak dan kewajiban yang sama dengan Muslim. Kedudukan ini terjadi melalui suatu perjanjian yang disebut perjanjian zimmah yang dibuat dengan penguasa Muslim. (Wali amri), yang kedua dalam Musta'min adalah seseorang yang masuk ke negara Islam dengan tidak bermaksud berdiam selamanya, tetapi terbatas dalam waktu tertentu dan melalui suatu perjanjian yang dinamakan "perjanjian keamanan" (akad aman) atau semata-mata diberi keamanan oleh penguasa. ${ }^{10}$

Pembagian dunia menjadi dar-al-Islam,darl al-harb dan darl-al ahdi belum dikenal baik pada masa Nabi, maupun pada periode Khulafa Al-Rasyidun. Kedua istilah ini baru muncul sekitar abad kedua dan ketiga hijriyyah (sekita abad ke 8 dan 9 M). Pada kedua abad ini sering berkobar api peperangan antara kaum Muslimin dengan rakyat negaranegara non Muslim, karena itu, wilayah non Muslim yang sering terlibat perang dengan kaum Muslimin itu disebut dar al-harb (wilayah perang). Jadi ijtihad yang berkenaan dengan pemberian nama tersebut didasarkan pada keagamaan yang pada waktu itu umumnya berdasarkan konflik dan perang. Berbeda dengan masa ketika teori tersebut dirumuskan, hubungan antar negara (hubungan internasional) saat ini berdasarkan perdamaian dibawah pengawasan PBB.

\section{PEMBAHASAN}

Menghadapi atau menangani suatu masalah. Politik merupakan kata kolektif yang mempunyai pemikiran-pemikiran yang bertujuan untuk mendapatkan kekuasaan. Pada umum nya dapat dikatakan bahwa politik (politics) adalah usaha untuk menentukan peraturan-peraturan yang dapat diterima baik oleh sebagian besar warga, untuk membawa masyarakat kearah kehidupan bersama yang harmonis. ${ }^{11}$

Menurut Miriam Budiardjo, politik adalah bermacam-macam kegiatan dalam suatu sistem politik atau negara yang menyangkut proses menentukan tujuan-tujuan dari sistem itu dan melaksanakan tujuan-tujuan itu. Selanjutnya sebagai suatu sistem politik adalah suatu konsepsi yang berisikan ketentuan-ketentuan siapa sumber kekuasaan negara,siapa pelaksana kekuasaan tersebut, apa dasar dan bagaimana cara untuk

10 Amir Syarifuddin, Ushul Fiqh, Jilid 1, Jakarta: PT. Logos Wacana Ilmu, h. 5

11 Atabik Ali, Kamus Kontemporer Bahasa Arab indonesia, Jakarta: Gema Insan Press, 2010. 
menentukan serta kepada siapa kewenangan melaksanakan kekuasaan itu diberikan, kepada siapa pelaksana kekuasaan itu bertanggung jawab dan bagaimana bentuk tanggung jawab nya. ${ }^{12}$

Pada dasarnya politik mempunyai ruang lingkup negara, membicarakan politik pada dasarnya membicarakan negara, karena teori politik menyelidiki negara sebagai lembaga politik yang mempengaruhi hidup masyarakat, jadi negara dalam keadaan bergerak. Selain itu politik juga menyelidiki ide-ide, azas-azas sejarah pembentukan negara, hakekat negara serta bentuk dan tujuan negara.

Pada hakikatnya hak politik di maksud untuk melindungi individu dari penyalahgunaan kekuasaan oleh pihak penguasa, karena negara sedikit banyak dianggap sebagai ancaman bagi manusia. Untuk melaksanakan hak politik, kewenangan pemerintah perlu dibatasi melalui perundang-undangan. Pelaksanaan beberapa hak politik secara khusus diberi pembatasan yaitu perundang-undangan yang menyangkut ketertiban dan keamanan nasional dalam negara masing- masing misalnya dalam kovenan sipil dan politik ditentukan bahwa hak berkumpul secara damai terkena pembatasan yang sesuai dengan undang-undang nasional dan yang dalam negara demokratis diperlukan demi kepentingan keamanan nasional atau keselamatan umum.

Untuk memantau perkembangan pelaksanaan hak-hak politik, didirikan panitia hak asasi (human right comittee), yang berhak menerima serta menyelidiki pengaduan dari suatu negara terhadap negara lain, jika telah terjadi pelanggaran terhadap hak asasi yang tercantum dalam kovenan itu.

Adapun di dalam hukum Islam hak politik memiliki arti Kata hak berasal dari bahasa arab yang secara etimologi mengandung beberapa arti, dalam al-quran terdapat beberapa makna untuk kata hak. Makna hak sebagai ketetapan dan kepastian terdapat dalam alquran surat yasin/36:7, makna hak sebagai menetapkan dan menjelaskan terdapat dalam surat al-anfal/8:8. Makna hak sebagai bagian yang tebatas terdapat dalam al-ma'arij/70:24-25. Kata hak dengan arti benar, lawan dari bathil, terdapat dalam surat yunus /10:35.16 Dalam kamus bahasa arab hak diartikan sebagai ketetapan, kewajiban, yakin, yang patut dan benar. Hak dapat juga disebut hak asasi yaitu, sesuatu bentuk yang dimiliki oleh seseorang karena kelahiran nya, bukan karena diberikan oleh masyarakat atau negara.

Pada dasar nya politik mempunyai ruang lingkup negara, membicarakan politik pada akhirnya adalah membicarakan negara, karena teori politik menyelidiki negara sebagai sebuah lembaga politik yang mempengaruhi hidup masyarakat. Politik juga ialah cara dan upaya menangani masalah-masalah rakyat dengan seperangkat undang-undang untuk mewujudkan kemaslahatan dan mencegah hal-hal yang merugikan bagi kepentingan manusia. ${ }^{13}$

Jadi penjelasan diatas yang dimaksud dengan hak politik dalam Islam adalah hak hak warga negara dalam negara Islam dimana individu dapat ikut andil melalui hak tersebut, dalam mengelola masalah-masalah negara atau pemerintahannya, misalnya hak

126 Undang-Undang Dasar Negara Republik Indonesia Tahun 1945 Pasal 4.

13 Farid Abdul Khaliq, Fikih Politik Islam, Jakarta: Sinar Grafika, 2005, h. 178. 
untuk memilih dan dipilih, hak untuk berkumpul dan hak berserikat (membentuk partai politik), hak untuk mengeluarkan pendapat termasuk mengawasi dan mengkritisi pemerintah apabila terjadi penyalahgunaan kewenangan, kekuasaan atau membuat kebijakan yang bertentangan dengan aspirasi rakyat.

Menurut al-Maududi paling tidak ada enam macam hak politik yang diakui dalam Islam, yaitu: ${ }^{14}$

1. Hak kebebasan untuk mengeluarkan pokok pikiran,pendapat,keyakinan. Hal ini lanjut Maududi, meliputi hak kebebasan untuk mengkritik pemerintah dan pejabatnya,termasuk kepala negara.

2. Hak untuk berserikat dan berkumpul.

3. Hak untuk memilih dan dipilih sebagai kepala negara.

4. Hak untuk menduduki jabatan umum dalam pemerintahan negara.

5. Hak untuk memilih dan dipilih sebagai ketua atau anggota Dewan Permusyawaratan Rakyat (DPR).

6. Hak untuk memberikan suara dalam pemilu.

a. Hak-Hak Pokok Warga Negara Dalam Hukum Islam dan Hukum Positif

Hukum positif merupakan aturan hukum yang sedang berlaku di suatu negara. Hukum positif disuatu negara tidak lah sama dengan hukum positif yang berlaku di negara lain. Perbedaan terletak pada konstitusi yang menjadi dasar dan sumber pembuatan hukum positif yang dimaksud. Hukum positif itu dapat berwujud peraturan perundang-undangan.

Di Indonesia konstitusi dimaksud telah mengalami beberapa kali penggantian, jika selama kurang lebih 4 tahun setelah kemerdekaan diberlakukan UUD 1945 maka selama kurun waktu sekitar 8 bulan berlaku konstitusi RIS hampir diseluruh indonesia, akan tetapi konstitusi ini diganti dengan UUDS 1950 yang kemudian dengan dekrit 5 juli 1959 dinyatakan tidak berlaku sekaligus memberlakukan kembali UUD 1945.

Ketiga konstitusi ini berbeda satu sama lain. UUD 1945 yang sangat singkat itu hanya mencantumkan pada pasal 28 tentang HAM dengan penanaman hak warga negara, sedangkan konstitusi RIS dan UUDS 1945 merinci HAM secara detail dalam 30 pasal yang ternyata cenderung memiliki kesamaan dengan Universal Declaration of Human Rights.

Pembukaan UUD 1945 yang menjiwai pengaturan HAM dalam batang tubuh UUD 1945 dan peraturan perundang-undangan lain sebagai hukum positif, pada setiap alinea mencerminkan adanya persamaan dibidang politik,Ekonomi, Hukum, Sosial, dan Budaya. Ini berarti substansi HAM dalam pembukaan UUD 1945 amat luas tetapi disayangkan kurang mendapatkan penjabaran yang lebih rinci dalam batang tubuh UUD 1945 oleh karena nya MPR melalui penetapan nomor : XVII/1998 maupun perubahan kedua UUD 1945 pasal 28 sampai dengan pasal 28J lebih memperjelas dan merinci mana yang merupakan HAM, kewajiban warga negara.

Pengaturan HAM dan kewajiban asasi manusia secara bersamaan dalam hukum positif bertujuan untuk menjaga keseimbangan antara kedua nya.26Individu memang

${ }^{14}$ Sugiyono, Metode Penelitian Kualitatif dan Kuantitatif, Bandung: Alfabeta, 2004, h. 244. 
memiliki hak-hak yang fundamental sebagai hak -hak azasi nya tetapi harus dituntut untuk dapat menghargai, menghormati dan menjunjung tinggi hak azasi individu yang lain, hal itu berarti dalam menjalankan hak azasinya setiap individu yang lain, hal itu berarti dalam menjalankanhak azasinya setiap individu tidak dapat mengabaikan apalagi melanggar hak azasi individu lain.

Adapun hak warga negara menurut UUD 1945 adalah:15

1) Hak warga negara untuk menjadi presiden dan wakil presiden (pasal 6 ayat 1)

2) Hak warga negara untuk memiliki kedudukan sama dalam hukum (pasal 27 ayat 1)

3) Hak atas penghidupan yang layak (pasal 27 ayat 2)

4) Hak dalam upaya pembelaan negara (pasal 27 ayat 3)

5) Hak berserikat dan berkumpul (pasal 28E ayat 3)

6) Hak mengeluarkan pendapat secara lisan dan tulisan (pasal 28)

7) Hak untuk memperoleh kesempatan dalam pemerintahan (pasal 28D ayat 3)

8) Hak untuk memeluk agama masing-masing (pasal 29 ayat 2)

9) Hak fakir miskin dan anak telantar dipelihara negara (Pasal 34 ayat 1 )

10) Hak warga negara untuk mendapatkan rasa aman atas apa yang dimiliki (Pasal 28G ayat 1)

Adapun hak-hak pokok warga negara didalam hukum Islam adalah hak-hak yang dibutuhkan manusia untuk menjaga kelangsungan eksistensinya dan keselamatan hidupnya. Apabila hak-hak pokok di langgar, maka menyebabkan berakhirnya kehidupan manusia atau kehidupan manusia mengalami kerusakan dan kehancuran yang parah. Dalam Islam, perlindungan atas kebutuhan pokok manusia bertumpu pada tujuan diturunkannya syariat Islam yaitu untuk melindungi dan memelihara kepentingan hidup manusia baik material maupun spiritual, individual, dan sosial.

Berdasarkan penelitian para ahli ushul fiqh bahwa Allah telah menurunkan syariat Islam dengan beberapa tujuan (Maqasid al-Tasyri atau Maqasid al-syari'ah ) yang secara garis besar terdiri dari tiga hal, yakni dharuriat (tujuan pokok), yaitu hal-hal penting yang harus dipenuhi untuk kelangsungan hidup manusia. Bila mana hal tersebut tidak di penuhi, maka akan terjadi kerusakan, kerusuhan dan kekacauan hidup manusia. Hajiyat (tujuan sekunder) yaitu hal-hal yang dibutuhkan oleh manusia untuk mendapatkan kelapangan dan kemudahan dalam hidup didunia, bila mana hal tersebut tidak terpenuhi, maka manusia akan mengalami kesulitan dan kesempitan dan tahsiniyat (tujuan tersier) yaitu hal-hal pelengkap yang terdyang baik. ${ }^{16}$

Adapun Hak warga negara secara umum di dalam Islam dalam buku DR. AM. Saefuddin berjudul Ijtihad Politik Cendekiawan Islam yang diterbitkan oleh Gema Insani (mei, 1966) adalah:17

a. Hak persamaan di depan hukum merupakan salah satu manifestasi prinsip persamaan yang dituntut oleh keadilan yang dicanangkan Islam, hukum yang dilaksanakan atas semua orang tanpa mengisti mewakan dan tanpa membedakan seorang individu

15 Undang-Undang Dasar RI dan perubahan nya, Penabur ilmu, Jakarta, hlm 8-27

16 Abdul wahhab Khallaf, Ilmu ushul figh, Pustaka Amani, Jakarta, 2003, cet 1 hlm 291

17 Saefuddin, Op. Cit, hlm. 8-16 
karena sebab jenis kelamin, warna kulit, kedudukan, kekayaan, kekerabatan atau persahabatan, bahkan akidah atau lainnya yang kontroversional.

b. Hak persamaan di depan peradilan dalam pemerintahan Islam, semua warga negara sama di depan peradilan, baik dari segi kepatuhan mereka terhadap keputusan, prosedur yang dipenuhi dalam melakukan dakwaan, dasar-dasar pengaduan, prinsipprinsip memutuskan, pelaksanaan keputusan, pelaksanaan hukum maupun kewajiban berlaku adil diantara orang yang berselisih. Tidak ada perbedaan satu individu dengan yang lain, bahkan musuh pun merasakan keadilan dan persamaan didepan peradilan ini.

c. Hak Kebebasan Individual, terdiri dari:

1) Hak kebebasan perorangan menurut ahli hukum kebebasan perorangan ialah kebebasan bagi tiap individu dalam perjalanan pulang pergi, terpeliharanya diri pribadi dari segala bentuk penganiayaan dan larangan menangkap, menyiksa, dan memenjarakan kecuali dengan tuntutan hukum, serta kebebasan berimigrasi ke luar masuk negara. Kebebasan perorangan menurut para ahli hukum ini, bahkan dengan pengertian yang lebih luas lagi, terjamin bagi tiap individu dalam pemerintahan Islam. Memusuhi kebebasan seperti ini merupakan tindak kezhaliman dan Islam mengharamkan nya secara mutlak. Perlindungan pemerintah Islam bagi individu terhadap tindak permusuhan atas kehidupan fisik maupun kehormatannya, tampak dalam hukuman yang berat bagi para pengganggunya yang tercantum dalam perundang-undangan Islam.

2) Hak kebebasan berkeyakinan dan beribadat bagi Non Muslim Islam tidak memaksa seseorang untuk mengubah keyakinannya dan memeluk Islam, walaupun Islam menyerukan untuk itu.

3) Hak bertempat tinggal dalam pemerintahan Islam, tiap individu menikmati hak nya bertempat tinggal, sehingga seorangpun tidak boleh masuk ke tempat tinggalnya kecuali dengan izin dan kerelaannya, karena tempat tinggal seseorang adalah tempat segala rahasia dan tempat menetap keluargany

4) Hak kebebasan bekerja dalam pemerintahan Islam, seorang individu berhak melakukan pekerjaan yang dikehendaki, baik perdagangan, perindustrian, ataupun pertanian, dengan syarat tidak melakukan pekerjaan yang diharamkan syariat Islam.

5) Hak kebebasan berpendapat dalam pemerintahan Islam, kebebasan berpendapat adalah hak individu yang mengantarkannya kepada kepentingan nuraninya yang tidak boleh dikurangi negara atau ditinggalkan oleh individu.

6) Hak menuntut Ilmu, Islam telah mewajibkan bagi negara untuk menyelenggarakan pengajaran bagi tiap anggota masyarakat. Dalam sunnah Nabi, kita menemukan fakta penting yang menunjukan bahwa kewajiban negara kepada tiap individu untuk memudahkan sarana-sarana memperoleh ilmu pengetahuan.

7) Hak menerima santunan negara, Maksud hak ini adalah bahwa seorang memperoleh jaminan umum dari negara ketika dijerat kebutuhan. Dalam pemerintahan Islam individu tidak mungkin menderita. 
b. Hak Memilih dan DiPilih Bagi Warga Negara Dalam Hukum Islam dan Hukum Positif

Hak dipilih didalam hukum positif sebagai pemenuhan Hak Asasi Manusia, ketentuan ini diatur ini di dalam pasal 43 Undang-Undang No 39 tahun 1999 tentang Hak Asasi Manusia (HAM) menyebutkan bahwa :18

1. Setiap warga negara berhak untuk dipilih dan memilih dalam pemilihan umum berdasarkan persamaan hak melalui pemungutan suara yang langsung, umum, bebas, rahasia, jujur, dan adil sesuai dengan ketentuan peraturan perundang-undangan.

2. setiap warga negara berhak turut serta dalam pemerintahan dengan langsung atau dengan perantaraan wakil yang dipilihnya dengan bebas, menurut cara yang ditentukan dalam peraturan perundang-undangan.

3. Setiap warga negara dapat diangkat dalam setiap jabatan pemerintahan .

Secara tegas koreksi terhadap penyelewengan orde baru juga dituangkan dalam penjelasan umum Bab III UU No. 25 tahun 2000 tentang program pembangunan nasional (propenas) 2000-2004.34 yaitu "Penegakan supremasi hukum berdasarkan nilai-nilai kebenaran dan keadilan serta penghormatan terhadap hak-hak asasi manusia secara universal mengalami degradasi. Kondisi tersebut, antara lain disebabkan oleh pemerintahan pada masa lalu tidak mencerminkan aspirasi masyarakat dan kebutuhan pembangunan yang bersendikan hukum agama dan hukum adat dalam pembangunan hukum".

Untuk itu, Pemerintahan Orde Reformasi ingin melakukan penataan ulang arah kebijakan hukum nasional sebagaimana tertuang dalam GBHN 1999. Arah kebijakan hukum dalam GBHN 1999 disebutkan antara lain:"Menata sistem hukum nasional yang menyeluruh dan terpadu dengan mengakui dan menghormati hukum agama dan hukum adat serta memperbaharui perundang-undangan warisan kolonial dan hukum nasional yang diskriminatif, termasuk ketidakadilan gender dan ketidaksesuaian dengan tuntutan reformasi melalui program legislasi".

Perintah dari MPR melalui GBHN 1999 tersebut emudian ditindaklanjuti dengan dikeluarkan nya UU No 25 tahun 2000 tentang Program Pembangunan Nasional (Propenas) tahun 2000 -2004, dengan melakukan penyusunan dan pembentukan peraturan perundang-undangan yang aspiratif dengan mengakui dan menghormati hukum agama dan adat melalui peningkatan peran legislasi nasional (Prolegnas).

Reformasi yang mengawali lengsernya orde baru pada awal tahun 1998 pada dasar nya merupakan gerak merefleksikan komitmen bangsa indonesia yang secara rasional dan sistematis bertekad untuk mengaktualisasikan nilai -nilai dasar demokrasi.

Nilai-nilai dasar tersebut antara lain berupa sikap transparan dan aspiratif dalam segala pengambilan keputusan politik, pers yang bebas, sistem pemilu yang jujur dan adil, dan prinsip good governance yang mengedepankan profesionalisme birokrasi lembaga eksekutif, keberadaan badan legislatif yang kuat dan berwibawa,kekuasaan kehakiman yang independen dan impartial, partisipasi masyarakat yang terorganisasi dengan baik serta penghormatan terhadap supremasi hukum.

18 Undang-Undang RI Nomor 39 Tahun 1999 tentang Hak Asasi Manusia, pasal 43. 
Selama Orde Baru, HAM sipil dan politik banyak dilanggar dengan alasan untuk menjaga stabilitas politik demi kelancaran pembangunan ekonomi, korupsi, kolusi, dan nepotisme merajalela, penyalahgunaan kekuasaan meluas, hukum merupakan subordinasi dari kekuasaan politik, Beberapa keputusan Mahkamah Agung jelas-jelas memperlihatkan pemihakannya terhadap kekuasaan, meski dengan akibat merugikan rakyat kecil, kebenaran dan keadilan sering dikesampingkan dengan alasan demi persatuan dan kesatuan bangsa, demi pancasila, demi kepentingan umum, demi asas kekeluargaan dan sebagainya, meski itu merugikan HAM. ${ }^{19}$

Di tengah perubahan besar saat ini, ketika sejumlah anggota masyarakat Indonesia muncul dengan peran baru, kekuasaan tidak lagi menjadi milik segelintir elite politik, kekuasaan terbesar dibanyak tempat dan kepada banyak orang. Mereka dulu lebih banyak pasif kini bangun mengambil prakarsa politik dan bertindak seolah-olah mendapat mandat paling besar untuk menegakkan nya. Proses dialogis tentang format dan sistem berbangsa dan bernegara menuju demokrasi pun kini menjadi menu seharihari. Sayangnya, pada situasi seperti ini justru proses penegakkan hukum masih saja mengalami banyak kendala bukan saja lantara warisan sistem hukum yang buruk di masa lalu, situasi belakangan ini juga mendatangkan proses identifikasi politik baru bagi warga negara dengan segala klaim nya tentang hak dan kewajiban.

Dalam rezim hukum internasional HAM, hak politik, terutama hak untuk memilih dan dipilih, termasuk berpartisipasi dalam pemerintahan, merupakan hak dasar bagi setiap warga negara tanpa terkecuali. Hal ini juga telah ditegaskan dalam pasal 27 ayat (1) UUD 1945 "setiap warga negara bersamaan kedudukan nya di dalam hukum dan pemerintahan dan wajib menjunjung hukum dan pemerintahan itu dengan tidak ada kecuali nya".36 Sebagaimana telah disahkan indonesia melalui UU No 12 tahun 2005 tentang pengesahan Kovenan Internasional tentang hak -hak sipil dan politik

Adapun di dalam hukum Islam ketentuan memilih dan dipilih menurut Islam, pemerintah adalah wakil (khalifah) dan yang maha pencipta alam semesta, tanggung jawab ini tidak di percayakan kepada individu atau keluarga atau sekelompok rakyat tertentu, tetapi kepada seluruh masyarakat Islam.

Hak politik menurut para ahli hukum adalah hak yang dimiliki dan digunakan seseorang dalam kapasitasnya sebagai anggota organisasi politik, seperti hak memilih (dan dipilih), mencalonkan diri dan memegang jabatan dalam negara, atau hak politik adalah hak-hak dimana individu memberi andil melalui hak tersebut dalam mengelola masalah-masalah negara. Islam menetapkan hak-hak politik tiap individu, diantaranya:20 a. Hak Memilih

Semua Individu memiliki hak memilih kepala negara dan anggota-anggota majelis syuro' (permusyawaratan). Siapa yang terpilih dijabatan ini, maka ia adalah kepala negara, dalam syara' disebut bai'ah, dan hak bai'ah ini adalah hak setiap muslim baik laki-laki atau perempuan.

b. Hak Musyawarah

19 Muladi, Demokratisasi Hak Asasi Manusia, dan Reformasi Hukum di Indonesi, Jakarta: The Habibie Center, 2002, h. 8-9. 36.

${ }^{20}$ Ahmad Muflih Sefuddin, Op.Cit, h.17. 
Hak musyawarah adalah hak bagi setiap Muslim kepada seorang khalifah (kepala negara). Tiap muslim mempunyai hak untuk bermusyawarah di dalam urusan-urusan yang perlu di musyawarahkan di dalam urusan-urusan yang perlu di musyawarahkan oleh kepala negara

\section{c. Hak Pengawasan}

Umat dan individu memiliki hak mengawasi kepala negara dan seluruh pejabat dalam pekerjaan dan tingkah laku mereka yang menyangkut urusan negara. Hak pengawasan ini dimaksudkan jika dia menyimpang dari kebenaran. Tahap pertama untuk meluruskan ialah memberi nasehat dengan ikhlas. Dalam Hadist yang yang diriwayatkan Imam Muslim dalam kitab

d. Hak Pemecatan

Islam telah memberi hak kepada umat memecat atau memberhentikan seorang kepala negara, jika ia keluar dari persyaratan seorang kepala negara atau tidak melaksanakan tugas dengan baik, hak ini ditegaskan oleh para ahli fiqh diantara nya Imam Ibnu Hazm Adz Dzohiri dari Ibnu Rajab Al-Hambali.

e. Hak Pencalonan dan Pemilihan

Hak Pencalonan adalah seseorang mencalonkan diri nya untuk salah satu jawaban pemerintahan atau fungsi umum. Apakah individu memiliki hak ini dalam pemerintahan Islam ? Jawaban nya boleh, karena rasulullah SAW telah mengabulkan permintaan Amru Ibnu Ash ketika dia memohon menjadi wali di negeri (wilayah) Oman.

f. Hak menduduki jabatan

Memegang suatu jabatan dalam syariat islam bukan hanya hak individu, melainkan kewajiban atas nya dari negara. Dalam hal ini, kewajiban kepala negara dan seluruh perangkatnya memilih orang yang paling cocok bagi tiap pekerjaan dalam pemerintahan. Tujuan pendirian negara tidak terlepas dari tujuan yang hendak dicapai oleh umat islam, yaitu memperoleh kehidupan didunia dan keselamatan diakhirat. Karena tujuan ini tidak mungkin di capai hanya secara pribadi-pribadi saja, maka Islam menekankan penting nya pendirian negara sebagai sarana untuk memperoleh tujuan tertentu.

Bukan hanya menjunjung tinggi hak-hak bagi umat muslim saja, Islam pun meletakkan hak-hak tertentu bagi non Muslim yang kebetulan hidup di dalam lingkungan perbatasan suatu negara Islam dan hak-hak ini dipandang sebagai bagian dari konstitusi Islam. Konstitusi Islam atau yang lebih dikenal dengan sebutan " Piagam Madinah" adalah sebutan dari shahifat (berarti lembaran tertulis ) dan kitab yang dibuat oleh Nabi. Kata Piagam berarti surat resmi yang berisi pernyataan pemberian hak, atau berisi pernyataan dan pengukuhan mengenai sesuatu.

Sudah menjadi cita-cita dan keinginan setiap orang, masyarakat atau bangsa dimana pun di dunia ini untuk memperoleh kehidupan yang baik dan sejahtera lahir dan bathin. Kondisi kehidupan yang demikian dapat tercapai apabila asas-asas keadilan, musyawarah, persatuan dan persaudaraan, persamaan hak dan kewajiban, ketaatan dan tolong menolong terhadap sesama terwujud dan terasa mempengaruhi seluruh aspek kehidupan masyarakat. Asas-asas ini sebagai telah disebut terdapat dalam Piagam Madinah yang bertujuan untuk menciptakan kelompok-kelompok sosial Madinah yang bertujuan untuk menciptakan kelompok-kelompok sosial Madinah menjadi masyarakat 
yang bersatu dan bekerja sama yang menjunjung tinggi nilai-nilai dan martabat manusia atas dasar persamaan dan keadilan.

Asas-asas tersebut juga terdapat dalam al-quran sebagai petunjuk dan perintah yang bersifat universal. Al-Qur'an berperan untuk memberikan bimbingan komprehensif ke arah tingkah laku manusia yang baik, baik perorangan maupun kelompok dalam upaya menciptakan suatu kehidupan yang selaras di dunia ini dengan tujuan akhir kehidupan abadi dialam akhirat. Fleksibilitas di pahami sebagai sifat lentur dan mudah menyesuaikan diri dengan unsur lain yang ada disekitarnya.

Fleksibilitas hukum islam berarti kelenturan hukum Islam dalam menghadapi berbagai permasalahan yang ada dimasyarakat. Kondisi masyarakat yang terus berubah menjadikan hukum islam harus mampu menjawab berbagai persoalan yang muncul, terutama berkaitan dengan masalah-masalah kontemporer yang belum pernah terjadi sebelumnya. Selain itu fleksibilitas hukum Islam juga dihadapkan dengan berbagai permasalahan baru yang dihadapi oleh hukum Islam karena kondisi waktu dan tempat yang berbeda-beda.

\section{c. Definisi Warga Negara Non Muslim Dalam Hukum Islam dan Hukum Positif}

Secara umum warga negara non Muslim dapat didefiniskan sebagai para penganut agama selain Islam yang menjadi warga negara non Muslim komunitas Islam yang kuantitasnya lebih sedikit dibanding warga negara mayoritas yang beragama Islam1. Islam mengakui ada nya pluralitas atau kemajemukan, baik dalam bidang agama,ras,dan kultur sebagai kehendak Allah. Islam hanya tidak mengakui paham pluralisme yang memandang semua agama sama. ${ }^{21}$

Dalam pandangan Islam, yang membedakan seseorang Muslim dengan non-Muslim adalah akidahnya yang termanifestasi kan dengan memeluk agama Islam. Perbedaan akidah merupakan perbedaan yang fundamental bagi Islam, sehingga menjadikan Islam tidak mentolerir secara teologis bahwa agama-agama lain sama dengan Islam. Meskipun demikian, Islam meyakini adanya pluralitas dalam kehidupan ini sebagai kehendak Allah. Menurut Nurcholis Madjid, tegak nya nilai-nilai hubungan sosial yang luhur, seperi pluralisme dan toleransi, termasuk didalamnya penghormatan dan pengakuan terhadap hak-hak minoritas. ${ }^{22}$

Adapun didalam Al-Qur'an non-Muslim disebut sebagai kafir, hal ini dikarenakan mereka tidak beriman kepada Allah dan Rasul-nya. Kata kafir sendiri secara bahasa berarti menutupi sesuatu, melepaskan diri, menghapus dan menyembunyikan kebaikan yang telah diterima, dan dari segi akidah, kafir berarti kehilangan iman.

Penyebutan kaum minoritas non Muslim yang menjadi warga negara Islam sebagai kaum dzimmi di pengaruhi oleh pandangan fiqh klasik yang membedakan dunia kedalam 3 wilayah, yakni wilayah Islam (Dar al-Islam) adalah suatu negara yang memerintah dengan kekuasaan kaum Muslimin. ${ }^{23}$ Adapun Dar al-Harbi ahli hukum Islam mempunyai dua pendapat definisi yaitu: Pertama Darul Harbi ialah suatu negara

${ }^{21}$ David Litle, John Kelsey, AbdulAziz A. Sachedina, Op.Cit, h. 46.

22 Anas Urbaningrum, Islam-Demokrasi Pemikiran Nurcholish Madjid, Jakarta: Republika, 2004, h. 146.

${ }^{23}$ M.Abu Zahrah, Hubungan Internasional Dalam Islam, Jakarta: Bulan Bintang, 1973, h. 61. 
(Darul) yang kekuasan dan pertahanannya di tangan penguasa bukan Muslimin, dan tidak mempunyai perjanjian apapun dengan kaum Muslimin, yang akan mengatur hubungan antar mereka, pendapat kedua adalah adalah definisi yang dibuat oleh golongan dan beberapa ahli hukum lain nya, mereka ini berpendapat suatu negara tidak mesti menjadi Darul Harbi semata-mata karena kekuatan dan pertahanan tidak ditangan kaum Muslimin. Selanjutnya yang ketiga adalah Dar Al-Ahdi yaitu suatu wilayah (negara) yang tadi nya wujud nya hanya dikira-kirakan saja ada nya, bagi kepentingan pembahasan ilmiah, tetapi akhirnya terdapat dalam kenyataan. Karena memang pernah terdapat beberapa suku atau negara yang tidak sepenuhnya tunduk kepada kaum Muslimin dan tidak pula masuk dalam pemerintahan Islam, akan tetapi mempunyai perjanjian (Ahdi) yang dihormati oleh pemerintah Islam dan mempunyai kedaulatan, sekalipun kadang-kadang tidak penuh.

Atas dasar ini kedaulatan negara Islam atas warga nya yang bukan Islam terbagi menjadi dua macam yaitu Dzimmi yaitu seorang bukan Muslim yang tinggal dalam wilayah negara Islam dengan ketentuan bahwa ia mempunyai hak dan kewajiban yang sama dengan Muslim. Kedudukan ini terjadi melalui suatu perjanjian yang disebut perjanjian zimmah yang dibuat dengan penguasa Muslim.(wali amri), yang kedua adalam Musta'min adalah seseorang yang masuk ke negara Islam dengan tidak bermaksud berdiam selamanya, tetapi terbatas dalam waktu tertentu dan melalui suatu perjanjian yang dinamakan "perjanjian keamanan" (akad aman) atau semata-mata diberi keamanan oleh penguasa.

Pembagian dunia menjadi dar-al-Islam,darl al-harb dan darl-al ahdi belum dikenal baik pada masa Nabi, maupun pada periode Khulafa Al-Rasyidun. Kedua istilah ini baru muncul sekitar abad kedua dan ketiga hijriyyah (sekita abad ke 8 dan 9 M)9.10 Pada kedua abad ini sering berkobar api peperangan antara kaum Muslimin dengan rakyat negara-negara non Muslim, karena itu, wilayah non Muslim yang sering terlibat perang dengan kaum Muslimin itu disebut dar al-harb (wilayah perang). Jadi ijtihad yang berkenaan dengan pemberian nama tersebut didasarkan pada keagamaan yang pada waktu itu umumnya berdasarkan konflik dan perang. Berbeda dengan masa ketika teori tersebut dirumuskan, hubungan antar negara (hubungan internasional) saat ini berdasarkan perdamaian dibawah pengawasan PBB.

Definisi ahl al-dzimmah berasal dari dua kata yang terpisah, yaitu ahl dan dzimmah. Secara etimologis kata ahl berarti kabilah atau suku dan sanak keluarga atau kerabat. Dalam Lisan al-Arab, Ibn Manzur mendefinisikan kata al-ahl dengan makna yang berbeda-beda sesuai dengan kata sambunganya. Jika di sambungkan dengan kata al-amr (ahl al-amr), berarti orang yang mengurusi masalah tersebut. jika disambungkan dengan kata al-rajul (ahl al-rajul), berarti orang-orang terdekat di sekitar orang tersebut. Jika disambungkan dengan nama semua nabi, makna nya adalah umatnya. ${ }^{24}$

\section{d. Hak dan Kewajiban Non Muslim dalam Islam}

Hak warga negara adalah suatu kewenangan yang dimiliki oleh warga negara guna melakukan sesuatu sesuai peraturan perundang-undangan.Dengan kata lain hak warga

${ }^{24}$ Syamsul Hadi Untung, Eko Adi Sutrisno, Op.Cit, h. 33. 
negara merupakan suatu keistimewaan yang menghendaki agar warga negara diperlakukan sesuai keistimewaan tersebut. Sedangkan kewajiban warga negara adalah suatu keharusan yang tidak boleh ditinggalkan oleh warga negara dalam kehidupan bermasyarakat dan bernegara. Kewajiban warga negara dapat pula diartikan sebagai suatu sikap atau tindakan yang harus diperbuat oleh seseorang warga negara sesuai dengan keistimewaan yang ada pada warga lain nya.

Dari pengertian di atas tersirat suatu makna bahwa hak dan kewajiban warga negara itu timbul atau bersumber dari negara. Maksudnya negaralah yang memberikan atau membebankan hak dan kewajiban itu kepada warganya. Pemberian / pembebanan yang dimaksud dituangkan dalam peraturan perundang-undangan sehingga warga negara maupun penyelenggara negara memiliki peranan yang jelas dalam pengaplikasian dan penegakkan hak serta kewajiban tersebut.

Di Indonesia konstitusi telah mengalami beberapa kali pergantian. Jika selama kurang lebih 4 tahun setelah kemerdekaan (18 agustus 1945- 27 Desember 1949) diberlakukan UUD 1945 maka sekitar kurun waktu 8 bulan (27 Desember 1949- 17 Agustus 1950) berlaku konstitusi RIS hampir diseluruh wilayah Indonesia. Akan tetapi konstitusi ini di ganti lagi dengan UUDS 1950 yang kemudian dengan Dekrit 5 Juli 1959 dinyatakan tidak berlaku sekaligus memberlakukan kembali UUD 1945. 25

\section{f. Pandangan Ulama dan Ahli hukum Indonesia terhadap hak dipilih non Muslim dalam hukum Islam dan hukum positif}

Dalam sejarah, boleh tidaknya non Muslim diangkat menjadi pemimpin kaum Muslim sesungguhnya merupakan fenomena klasik yang senantiasa mengundang perdebatan dikalangan ulama dan pemikir politik Islam dari masa ke masa. Disatu sisi, sebagian ulama menganggap bahwa non Muslim tidak boleh diangkat sebagai pemimpin non Muslim atas dasar surat Al-imran:3:118, Al-maidah:5:51 dan Al-Imran:3:28 karena ayat ini lah yang dipakai sebagai argumen bahwa orang-orang Muslim dilarang mengambil orang-orang non Muslim untuk menjadi wakil kepercayaan dan menjadi pemimpin orang-orang Muslim, adapula beberapa ulama yang memandang bahwa esensi perdebatan bukan terletak pada apakah pemimpin harus harus orang Islam atau tidak, melainkan yang terpenting adalah apakah seseorang pemimpin mampu memimpin masyarakat memperoleh kesejahteraan dan keadilan yang merupakan perintah Al-Qur'an dan hadist Nabi SAW.

Secara umum perbedaan pendapat para ulama tentang pemimpin non Muslim dapat digolongkan menjadi dua kelompok yang pertama, mereka yang menolak pemimpin Non Muslim antara lain Al-jassas, Al-Alusi, Ibn Arabi, Kiya Al-Harasi, Ibn Kasir, AsSubuni, Az-zamakhsyari, Ali as-Sayis, Tabataba'i, Al-Qurtubi, Wahbah az-Zuhaili, asSyaukani, al-Tabari, Sayyid Qutb, Al-Mawardi, Al-Juwaini, Abdul Wahhab Khallaf, Muhammad Diya as-Din ar-Rayis, Hasan al-Banna, Hasan Islail Hudaibi, Al-Maududi, dan Taqi ad-Din an-Nabhani.

25 Majda El Muhtaj,Hak Asasi Manusia dalam Konstitusi Indonesia, Jakarta: Prenada Media, 2005, h. 25. 
Dan menurut Mujar ibnu Syarif menegaskan bahwa mengakat orang-orang kafir sebagai pemimpin umat Islam justru lebih berbahaya daripada kekafiran kaum kafir dan kemusyrikan kaum musyrik. Kaum kafir itu lanjut thabathaba'i adalah musuh umat Islam, dan bila musuh itu telah diambil sebagai teman, maka kala itu ia telah berubah menjadi musuh dalam selimut yang jauh lebih sulit untuk dihadapi ketimbang musuh yang nyata-nyata berada diluar lingkungan umat Islam. ${ }^{26}$

Di kalangan umat Islam yang tergolomg paling keras menolak presiden non-Muslim adalah Sayyid Qutb. Lebih dari itu ia bahkan berpendapat, sekedar menolong atau mengadakan perjanjian persahabatan dengan non Muslim saja, utamanya dengan kaum Yahudi dengan Nasrani, umat Muslim tidak diperbolehkan melakukannya.

Adapun kelompok kedua yang meperbolehkan mengangkat non Muslim sebagai pemimpin antaralain: Menurut Syekh Muhammad al-Ghazali yang dikutipan oleh Fahmi huwaidi mengatakan bahwa:"Islam memandang bahwa kelompok-kelompok yang mengikat perjanjian dengan orang-orang Islam, baik dari kalangan yahudi maupun nasrani secara politis dan kebangsaan mereka mempunyai hak dan kewajiban yang sama dengan kaum muslim, Islam membangun prinsip sosial berdasarkan prinsip saling membahu dan bekerja sama. Mengenai ayat yang menerangkan bahwa umat Islam dilarang mengambil seorang pemimpin atau menjadikan teman kepercayaannya, Syekh Muhammad al-ghazali mengatakan bahwa ayat ini turun dalam konteks orang-orang non Muslim yang berbuat sewenang-wenang dan memerangi umat Muslim. Dalam kondisi seperti ini orang-orang Muslim tidak boleh mengangkat mereka menjadi seorang pemimpin atau menjadikan teman kepercayaan. ${ }^{27}$

Sedangkan Farid Abdul Khaliq mengatakan "umat non Muslim mempunyai hak sepenuhnya seperti yang dimiliki oleh umat Muslim, mereka memiliki hak sepenuhnya seperti yang dimiliki oleh umat Muslim, mereka memiliki hak yang sama sepenuhnya seperti yang dimiliki oleh umat Muslim, mereka memiliki hak yang sama untuk memilih dan dipilih presiden atau duduk diparlemen. Menurutnya prinsip persamaan yang dijadikan dasar utama. Seperti yang telah dibuktikan dalam sejarah awal pemerintahan Rasulullah di Madinah yang terdapat dalam piagam Madinah, bahwa orang yahudi memiliki hak dan kewajiban yang sama dengan umat Muslim. Mereka pun diakui sebagai warga negara yang satu umat dengan catatan mereka patuh terhadap undangundang yang berlaku dan tidak memerangi umat Islam karena agama serta memiliki sifat berbuat adil.

Menurut Hasan Al-Turobi ketua Front Islam Nasionalis Sudan di depan kongres berdiri nya organisasi ini yang dikutip oleh Fahmi Huwardi mengatakan bahwa:

"Kita berharap agar penduduk dan warga negara merasa tentram termasuk ahlu kitab pada umum nya dan pada masyarakat kristen khusus nya ini karena dasar-dasar agama kita lebih dekat dengan dasar-dasar agama mereka, memberi keluasan kepada kita dan kepada mereka, sedangkan undang-undang lain dimuka bumi tidak memberikan keluasan seperti ini. Baik kita maupun mereka memiliki risalah samawi yang didasarkan

${ }^{26}$ Mujar Ibnu Syarif, Op.Cit. h.46.

${ }^{27}$ Fahmi Huwaidi dkk, Kebangkitan Islam dalam Perbincangan Para Pakar, Jakarta: Gema Insani Press, 1998, h.168 
atas mata rantai Rasul baik kita maupun mereka serupa didalam keimanan, baik akhlak, ibadah, dan tanggung jawab dihadapan nya. Ia menjelaskan pemberlakuan hukumhukum Islam yang mengandung ajaran kebebasan akidah, kebudayaan, kehidupan umat Muslim dan ahli kitab yang memegang akidah masing-masing. Dasar-dasar syariat Islam menjamin hak-hak umum warga negara non Muslim dan Muslim selama mereka berkomitmen dengan kewajiban umum, serta saling memberikan loyalitas antar sesama warga. Mereka memiliki hak dan kewajiban seperti kita.

Adapun menurut ahli hukum di Indonesia mantan ketua Konstitusi (MK) Mahfud M.D menilai tidak ada persoalan perbedaan agama dikalangan masyarakat Indonesia saat ini. "Saya melihat ditingkat rakyat tidak ada masalah perbedaan agama." kata mahfud saat menjadi pembicara dalam dialog bertajuk "kepemimpinan bangsa yang bermartabat dan berkeadilan" di Jakarta, Senin 17 April 2017.

Mahfud M.D menyampaikan kebebasan memilih kepala daerah ini sejalan dengan pernyataan bung karno kala menetapkan Indonesia sebagai negara pancasila yang berketuhanan dan berkeadilan."Negara pancasila itu berketuhanan, mengakui dan melindungi semua agama. Bung karno bilang kalau orang Islam ingin Indonesia negara yang Islami ya pilih pemimpin Islam, begitu juga kalau ingin gedung-gedung ber-letter kristen ya pilih pemimpin non Muslim. itu semua aspirasi, tidak boleh ribut karna itu. ${ }^{28}$

Adapun pendapat Todung Mulya Lubis sebagaimana di kutip dalam buku nya In search of Human Right legal political Dilemmas Of Indonesia's New Order bahwa dengan hilang nya hak memilih dan dipilih sebagian warga negara, secara tidak langsung negara telah melanggar hak-hak asasi manusia yang pada saat ini sedang gencar-gencar nya didengungkan oleh sebagian besar negara-negara didunia berupa hak dipilih dan hak untuk memilih.55 Dan menurut Jimly Asshiddiqie mengatakan tidak mempermasalahkan apabila ada calon presiden dari kalangan non Muslim. Pencalonan presiden dari kalangan non Muslim tidak berbenturan dengan hukum yang ada. "Ya boleh secara hukum tidak boleh di munafikan. boleh-boleh saja dari segi hukum".

\section{g. Persamaan dan Perbedaan Hak-Hak Politik Warga Negara Non Muslim Dalam Pandangan Hukum Islam dan Hukum Positif}

Dari uraian di atas dapat di ketahui bahwa berdasarkan Hukum Islam dan hukum positif sama-sama mengakui hak persamaan dan kebebasan karna pada hakikatnya umat manusia itu di lihat dari hakikat penciptaannya, tidak ada perbedaan satu sama lain, mereka semua sama, yakni sama-sama keturunan Adam. Adapun di dalam hukum Islam semua manusia mempunyai persamaan hak tanpa memandang warna kulit, suku,maupun agama.

Adapun di dalam hukum positif tidak ada satu pun aturan yang menghalangi hak politik non Muslim karna didalam hukum positif memandang setiap warga negara berkedudukan sama didepan hukum dan pemerintahan berdasarkan pasal 27 ayat 1.Kemudian di dalam UDHCR pasal 2 dijelaskan bahwa setiap orang mempunyai hak-

28 54http://www.opinibangsa.id/2017/mahfud-md-persoalaan-di-masyarakat-bukan.html?m=1, diakses pada 17/5/2017. 
hak dan kebebasan-kebebasan yang tercantum di dalam deklarasi ini tanpa perbedaan apapun seperti perbedaan ras, warna kulit, jenis kelamin, bahasa, agama.

Baik di dalam hukum Islam atau pun hukum positif kedua nya mengakui hak persamaan dan kebebasan bagi setiap manusia, akan tetapi ada perbedaan dari keduanya. Jika hukum Islam memberikan argumen tersebut berdasarkan al-Qur'an dan Sunnah yang menjadi Undang-Undang tertinggi bagi kaum Muslimin, yang mana Undang-Undang tersebut berasal dari Allah dan Rasulnya.Tidak ada seorang Muslim pun yang berhak menetapkan suatu hukum dalam suatu perkara yang hukum nya telah ditetapkan.

Sedangkan hukum positif yang dianut oleh negara Indonesia (UDHR) yang dilahirkan PBB. Hukum yang dianut oleh negara Indonesia merupakan buatan manusia, karena itu segala sesuatunya berpusat kepada manusia sebagai tolak ukur segala sesuatu. Meskipun keduanya sama-sama menganut konsep kesetaraan, hak persamaan dan kebebasan bagi seluruh manusia akan tetapi sumber dari kedua hukum ini berbeda. Jika hukum Islam bersumber dari al-Qur'an dan Sunnah yang mana hukum tersebut dari Allah dan Rasulnya yang menentukan. Sedangkan hukum positif bersumber dari barat dan manusialah yang membuat dan menentukan hukum tersebut.

\section{PENUTUP}

Mengenai hak asasi tiap warga negara memiliki hak dan kewajiban yang sama dengan umat Muslim di dalam hukum Islam maupun hukum Positif dan dalam pelaksanaan hak asasi yang berkaitan dengan hak politik kaum non Muslim yang menjadi warga negara Islam atau negara yang mayoritas penduduk nya beragama Islam didalam hukum Islam dan hukum positif mempunyai hak politik sebagaimana kaum Muslimin, yaitu hak untuk mengeluarkan pendapat dalam masalah-masalah politik, hak untuk berserikat dan berkumpul, hak untuk menduduki jabatan umum dalam pemerintahan, hak untuk memilih dan dipilih untuk menduduki jabatan umum dalam pemerintahan, hak untuk memberikan suara dalam pemilu.Mengenai hak dipilih dalam hukum positif tidak ada aturan yang melarang non Muslim untuk dipilih dalam menduduki jabatan umum dalam pemerintahan, sedangkan hak dipilih non Muslim dalam nash Al-Qur'an untuk melarang umat Muslim dalam mengambil non Muslim menjadi pemimpin dalam surat Al-Imran:3:118, Al-Maidah:5:51, Al-Imran:28. Ayat ini lah yang dipakai sebagai argumen tidak boleh mengambil orang-orang non Muslim menjadi wakil kepercayaan dan pemimpin orang Muslim.Mengenai jabatan pemerintahan dan perwalian dalam pandangan politik Islam para ulama berbeda pendapat. Ulama klasik yang menganut sitem tradisional mengatakan umat non Muslim hanya boleh memegang jabatan yang bersifat umum sedangkan jabatan-jabatan kunci mereka tidak diberi hak untuk menjabatnya, dan kedudukan mereka sebagai warga ahlu dzimmi. Sedangkan ulama yang menganut teori sistem politik modern berpendapat bahwa Muslim sama kedudukan nya dengan non Muslim mereka memiliki hak-hak dan kewajiban yang sama, kedudukan mereka sama yaitu sama-sama sebagai warga masyarakat. Adapun dalam konteks Indonesia mengenai hak dipilih warga negaraa non Muslim berhak dipilih 
menjadi pemimpin atas kaum Muslim dimana penamaan kaum dzimmi pada zaman klasik dikarenakan banyaknya peperangan pada zaman itu antara Muslim maupun non Muslim, begitu juga larangan dipilih berdasarkan surat Al-Maidah ayat 51 yang hanya berlaku dalam konteks peperangan dan tidak relevan diterapkan pada zaman sekarang dimana hak asasi manusia telah diatur didalam Undang-Undang karna Islam mengusung prinsip persamaan.

Berdasarkan Hukum Islam dan hukum positif sama-sama mengakui hak persamaan dan kebebasan karna pada hakikatnya umat manusia itu dilihat dari hakikat penciptaannya, tidak ada perbedaan satu sama lain, mereka semua sama, yakni samasama keturunan Adam. Baik di dalamn hukum Islam atau pun hukum positif kedua nya mengakui hak persamaan dan kebebasan bagi setiap manusia, akan tetapi ada perbedaan dari kedua nya. Jika hukum Islam memberikan argumen tersebut berdasarkan al-Qur'an dan Sunnah yang menjadi Undang-Undang tertinggi bagi kaum Muslimin, yang mana Undang-Undang tersebut berasal dari Allah dan Rasulnya.Tidak ada seorang Muslim pun yang berhak menetapkan suatu hukum dalam suatu perkara yang hukum nya telah ditetapkan, sedangkan hukum positif yang dianut oleh negara Indonesia (UDHR) yang dilahirkan PBB. Hukum yang dianut oleh negara Indonesia merupakan buatan manusia, karena itu segala sesuatunya berpusat kepada manusia sebagai tolak ukur segala sesuatu. Meskipun keduanya sama-sama menganut konsep kesetaraan, hak persamaan dan kebebasan bagi seluruh manusia akan tetapi sumber dari kedua hukum ini berbeda. Jika hukum Islam bersumber dari al-Qur'an dan Sunnah yang mana hukum tersebut dari Allah dan Rasulnya yang menentukan. Sedangkan hukum positif bersumber dari barat dan manusialah yang membuat dan menentukan hukum tersebut.

\section{DAFTAR PUSTAKA}

\section{Buku}

Abdul Rasyid, Ilmu Politik Islam, Bandung: Pustaka, 2017.

Abdul Wahhab Khallaf, Ilmu Ushul Figh, Jakarta: Pustaka Amani, 2003.

Abul A'la Maududi, Hak-Hak Asasi Manusia dalam Islam, Jakarta, PT Bumi Aksara, 2018.

Amir Syarifuddin, Ushul Figh, Jilid 1, Jakarta: PT. Logos Wacana Ilmu.

Anas Urbaningrum, Islam-Demokrasi Pemikiran Nurcholish Madjid, Jakarta: Republika, 2004. AS, Metodelogi Penelitian, Bandar Lampung: LP2M IAIN Raden Intan.

Atabik Ali, Kamus Kontemporer Bahasa Arab Indonesia, Jakarta: Gema Insan Press, 2010.

Ayi Sofyan, Etika Politik Islam, Bandung, Pustaka Setia, 2012.

David Litle dkk, Kebebasan Agama dan Hak-Hak Asasi Manusia, Bandung: Pustaka Pelajar, 2015.

E.I.J Rosenthal, Islam Is The Modern Nasional State, Cambridge, 2016.

Fahmi Huwaidi dkk, Kebangkitan Islam dalam Perbincangan Para Pakar, Jakarta: Gema Insani Press, 1998.

Farid Abdul Khaliq, Fikih Politik Islam, Jakarta: Sinar Grafika, 2005.

Hasbi ash-Shiddieqy, Hukum Antar Golongan Dalam Fiqih Islam, Jakarata: Pustaka Amani, 2014.

Inu Kencana Syafiie, Ilmu Politik, Rineka Cipta, Jakarta, 2010. 
J.Moelang, Metode Penelitian Kualitatif, Bandung: Remaja Rosada Karya, 1997.

Juliansyah Noor, Metodologi Penelitian, Jakarta: Kencana Prenada Media Grup, 2011.

Kartini Kartono, Pengantar Teknologi Riset Sosial, Bandung: Mandar Maju, 1996.

M. Abu Zahrah, Hubungan Internasional Dalam Islam, Jakarta: Bulan Bintang, 1973.

Majda El Muhtaj, Hak Asasi Manusia dalam Konstitusi Indonesia, Jakarta: Prenada Media, 2005.

Moh Mufid, Politik Dalam Perspektif Islam, Jakarta: Jakarta Press, 2013.

Muflih Saefuddin, Ijtihad Politik Cendekiawan Muslim Islam, Jakarta: Gema Insani, 2015.

Mujar Ibnu Syarif, Hak-Hak Politik Minoritas Non Muslim dalam Komunitas Islam, Bandung: Angkasa, 2013.

Muladi, Demokratisasi Hak Asasi Manusia, dan Reformasi Hukum di Indonesi, Jakarta: The Habibie Center, 2012.

Sugiyono, Metode Penelitian Kualitatif dan Kuantitatif, Bandung: Alfabeta, 2004.

Jurnal

Abu Tholib Khalik, 2014 "Pemimpin non Muslim Perspektif Ibnu Taimiyyah", Jurnal Studi Keislaman, Volume 14 No 1.

Mary Silvia, 2012. "Islam dan Kaum Non Muslim Dalam Piagam Madinah", Jurnal Refleksikal, Volume 13 N0 3.

Eko Adi Sutrisno, 2014, "Sikap Islam terhadap Minoritas Non Muslim", Jurnal Kalimah, Volume 12 No 1.

Peraturan Perundang-Undangan

Undang-Undang Dasar RI dan Perubahannya, Penabur Ilmu, Jakarta.

Undang-Undang Dasar Negara Republik Indonesia Tahun 1945.

Undang-Undang RI Nomor 39 Tahun 1999 tentang Hak Asasi Manusia.

Internet/media online

54http:/ / www.opinibangsa.id/2017/ mahfud-md-persoalaan-di-masyarakatbukan.html?m=1, diakses pada 17/5/2017. 